\title{
The relationship between microstructure and mechanical properties of directly bonded copper-alumina ceramics joints
}

\author{
K. PIETRZAK*, W. OLESINSKA, D. KALINSKI, and A. STROJNY-NEDZA \\ Institute of Electronic Materials Technology, 133 Wolczynska St., 01-919 Warsaw, Poland
}

\begin{abstract}
The effect of phase transformations induced in the surface layer of alumina ceramics during its direct joining with copper activated with oxygen or titanium on the mechanical strength of the ceramic/copper joints was examined. The materials used in the experiments were an alumina single crystal, alumina ceramics $\left(97.5 \mathrm{wt} \% \mathrm{Al}_{2} \mathrm{O}_{3}\right)$, the cermet mixtures: $\mathrm{Cu}-\mathrm{Cu} \mathrm{u}_{2} \mathrm{O}$ with $10-50$ wt $\%$ of $\mathrm{Cu}_{2} \mathrm{O}$, copper with 5 wt $\%$ of Ti, and copper with $5 \mathrm{wt} \%$ of $\mathrm{Ti}$ and $10 \mathrm{wt} \% \mathrm{of} \mathrm{Ag}$. The microstructure of the transition layer was examined by the X-ray diffraction method (XRD), scanning electron microscopy method (SEM) and energy dispersive x-ray spectroscopy (EDX). The mechanical strength of the joints was measured using the three-point bending method. The amount of oxygen optimal for the joining process was determined. It has been demonstrated that the cohesion of the joints depends not only on the formation of the individual phases but also, or even primarily, on the microstructure of the transition layer formed between them.
\end{abstract}

Key words: directly bonded copper-alumina ceramics joints.

\section{Introduction}

The applications of ceramics in electronics almost always require that the ceramics should be joined with metals. The electro-insulating substrates with conducting metallic paths or the encapsulations of semiconductor components are bonded complexes of various materials with greatly differing properties. Most of them are exploited under extremely severe conditions and are exposed to heavy thermal- and mechanical loads, whereas even after their long-term exposure to these conditions they must preserve their very good strength parameters, high vacuum-tightness, and satisfactory electro-insulating and thermal properties [1].

Successful joining of the materials with widely varied properties depends on whether the liquid phase (oxide or metallic), formed during the joining process wets satisfactorily their surface, whereas their mechanical strength depends on the relaxation of the residual stresses generated when the joint is cooled from the high temperature that prevails during brazing. The condition of good wettabillity is that the materials to be joined should be chemically compatible, whereas the relaxation of the residual stresses can be achieved when their physical properties are compatible [2-5]. In the case of the widely differing materials, these conditions cannot be fulfilled, and the solution is that an interlayer (e.g. in graded form [6]) with intermediate properties should be formed between the two materials during the process of their joining. Some positive results can be achieved using the ultrasonic vibrations [7].

The metallic layers produced on ceramic materials, aimed to function as the contact surfaces or surfaces which enable joining the ceramics with metals for the purposes of electronics, high vacuum techniques, and nuclear techniques, have long research and industrial traditions. In the techniques used so far, the metallic layers produced on ceramics have usually been high-melting materials (W, Mo), noble metals ( $\mathrm{Ag}, \mathrm{Au}$, $\mathrm{Pd}$ ), and copper or nickel which are good electric and thermal conductors [8], and were deposited as sintered powders added with glasses.

In order to satisfy the condition of chemical compatibility of the ceramic materials, multi-component ceramic composites, and complex metallic alloys with so much differing chemical, physical, and thermal properties it is necessary to carefully select the physicochemical conditions (such as temperature, gaseous atmosphere) of the process of their joining. Ceramics with metals in the presence of glasses are usually joined in complex oxidation-reduction atmospheres since these are necessary for the chemically-compatible phases to form (e.g., surface oxidation of all the metallic components). They must occur in order to achieve simultaneously the wettability of the ceramic and metal by the glasses and then the reduction of these oxides during the cooling stage so as, during brazing, the layers produced can be wetted by the molten metal. The processes that proceed during the formation of the metallic layers are complex, since apart from the physical processes (melting and migration of the molten phases) we may have chemical ones as well; such reaction takes place not only between the individual components, but also between these components and the protective atmosphere or the ceramic substrate. Moreover, new phases appear, such as e.g. aluminum-magnesium spinels $\left(\mathrm{MnAl}_{2} \mathrm{O}_{4}\right)$, which are responsible for joining the metallic layers with ceramic substrate.

Direct joining techniques in which the metallic layer is not pre-deposited on the ceramic but some active elements, such as oxygen or titanium, are introduced into the metal so as to enable certain ceramic-wetting phases to form. The

*e-mail: katarzyna.pietrzak@itme.edu.pl 
process of wetting oxide- and non-oxide ceramics by metallic alloys added with titanium have extensively been studied within a wide range of chemical compositions and contents of the active elements. The studies included examinations of the wetting angles of various solders added with active metals ( $\mathrm{Ti}, \mathrm{Mn}, \mathrm{Zr}, \mathrm{V}$ ), and of the surface phase transformations that occur in the transition layer formed on the ceramic after they were melted. The results are however divergent, especially those concerning the dependence of the wetting angles on the process parameters (kind of the ceramic substrate, protective atmosphere) [9-12]. At high temperatures, various phase transformations occur with the participation of these active elements as a result of their reaction with the components of the materials being joined. Various intermetallic and oxide phases are formed which degrade the wettabillity and are little resistant to mechanical loads. To achieve good mechanical strength of the transition layer, it is desired that these phases should be highly plastic, whereas most intermetallic compounds have poor resistance to brittle fracture.

An improvement of the fracture toughness of oxide- and non-oxide ceramics can be achieved by using Ti for the formation of the metallic surface layer which contains phases with high plasticity, described as $\mathrm{Me}_{\mathrm{x}} \mathrm{M}_{\mathrm{y}} \mathrm{X}_{\mathrm{z}}$ by Nowotny [13] where $\mathrm{Me}$ - metal from the transition group (III-IV), M metal from the main group or silicon, $\mathrm{X}$ - non-metal $(\mathrm{C}, \mathrm{N}$, $\mathrm{O}), \mathrm{x}, \mathrm{y}, \mathrm{z}-$ numeric indices.

Among these phases the most interesting are $\mathrm{M}_{6} \mathrm{O}$ $\left(\mathrm{Ti}_{3} \mathrm{Cu}_{3} \mathrm{O}, \mathrm{Ti}_{4} \mathrm{Cu}_{2} \mathrm{O}\right)$ chiefly identified in joining oxide ceramics [11] and $\mathrm{Me}_{6} \mathrm{C}$ and $\mathrm{Me}_{6} \mathrm{~N}$ which appear in joining nitrogen ceramics and carbides [14]. According to Stobierski [11] in the structure of these compounds a laminar order of chemical bounds is found. There are layers built of $\left[\mathrm{Me}_{6} \mathrm{X}\right]$, which are bonded mutually by metal layers $\mathrm{M}$. Thanks to this structure, their properties, essential for the joining process (e.g. thermal expansion coefficient) are intermediate between those typical of ceramics and those characteristic of metals, together with a high fracture toughness which enables the residual stresses, generated in the joints during cooling, to be relaxed. Preparation of these compounds is difficult since it requires high temperatures and high pressures [13]. In favorable conditions, the $\mathrm{M}_{6} \mathrm{O}$ and $\mathrm{M}_{6} \mathrm{X}$ phases are found in the surface layers after the joining processes. Keller et al. [14] and Eustahopoulus [11] identified the $\mathrm{M}_{6} \mathrm{O}$ phases $\left(\mathrm{Ti}_{3} \mathrm{Cu}_{3} \mathrm{O}\right.$ and $\mathrm{Ti}_{4} \mathrm{Cu}_{2} \mathrm{O}$ ) on the surface of alumina, whereas Olesińska et al.[15] report on the presence of the $\mathrm{M}_{6} \mathrm{C}$ phase on the $\mathrm{SiC}$ substrate after joining. In both oxide- and non-oxide ceramic materials, the surface processes are extremely important since these materials are not wetted by molten metal's, whereas the formation of new phases during joining with the participation of active oxygen or titanium always proceeds with the interference into the structure of the near-surface layer of the substrate [17-19].

Similar phenomena take place during active oxygenassisted direct reactive joining of alumina with copper, known as the Copper Direct Bonding (CDB), in which the joint is formed through the synthesis of copper oxides with alumina in the presence of the molten $\mathrm{Cu}-\mathrm{Cu}_{2} \mathrm{O}$ eutectic which well wets the ceramic surface [7,8]. The synthesis of the $\mathrm{Al}_{2} \mathrm{CuO}_{4}$ and $\mathrm{AlCuO}_{2}$ aluminum-copper spinels on the ceramic surface (according to the reactions 1, 2, 3 and 4 given below) is promoted by the in-statu-nascendi oxygen released during the reduction of copper oxides:

$$
\begin{gathered}
2 \mathrm{CuO} \rightarrow \mathrm{Cu}_{2} \mathrm{O}+1 / 2 \mathrm{O}_{2}, \\
\mathrm{Cu}_{2} \mathrm{O} \rightarrow 2 \mathrm{Cu}+1 / 2 \mathrm{O}_{2}, \\
\mathrm{Cu}_{2} \mathrm{O}+\mathrm{Al}_{2} \mathrm{O}_{3} \rightarrow 2 \mathrm{CuAlO}_{2}, \\
\mathrm{Cu}_{2} \mathrm{O}+\mathrm{Al}_{2} \mathrm{O}_{3}+2 \mathrm{Cu}+2 \mathrm{O}_{2} \rightarrow 2 \mathrm{Cu}_{2} \mathrm{AlO}_{4} .
\end{gathered}
$$

The new phases which form during the diffusion processes with the participation of oxygen or titanium etch and degrade alumina. However, if together with these effects the plasticity of the transition layer increases they may favor the relaxation of the thermally-generated residual stresses and thereby prevent the joint from an accidental damage, which may occur even under low mechanical or thermal loads.

In joining ceramic with copper, the relaxation of the residual stresses induced in the transition layer may also be promoted by doping the copper with oxides, since the thermal expansion coefficients of copper-copper oxides mixtures are smaller than that of copper $\left(\alpha_{\mathrm{Cu}}-18 \times 10^{-6} \mathrm{~K}^{-1}, \alpha_{\mathrm{Cu}_{2} \mathrm{O}}-\right.$ $4.3 \times 10^{-6} \mathrm{~K}^{-1}$ and $\left.\alpha_{\mathrm{CuO}}-9.3 \times 10^{-6} \mathrm{~K}^{-1}\right)$. This technique permits producing cermets with various thermal properties, advantageous for the relaxation of the residual stresses in the joints and also favors changes of the character of deformation of the joints when under load.

The aim of the present study was to examine how the phase transformations that occur on the surface of alumina during its joining with copper in the presence of oxygen and titanium affect the mechanical strength of the ceramic-copper joints. The synthesis of the spinels phases and the $\mathrm{M}_{6} \mathrm{O}$ phases on the surface of leuco-sapphire and alumina ceramics was examined in vacuum and in a nitrogen atmosphere with the oxygen content of about $1.5 \mathrm{ppm}$. The knowledge of these phenomena is vital in engineering of complex multi-component materials, ceramic materials and metals.

\section{Experiments}

The experiments were conducted with corundum ceramic plates with about $97 \mathrm{wt} \%$ of $\mathrm{Al}_{2} \mathrm{O}_{3}$, and polished plates cut of a leuco-sapphire produced at Institute of Electronic Materials Technology (ITME). Copper, copper oxides, titanium hydride and silver were used in the form of commercial powders with a purity of $99.9 \%$. The compositions (in wt $\%$ ) of the mixtures are given in Table 1 . The powder mixtures were annealed and melted on the surface of corundum at various temperatures and in various atmospheres and, then, directly used for joining of the ceramic.

The mixtures were used for preparing test samples intended for:

- the phase examinations - copper added with copper oxides, titanium, and silver annealed on the alumina surface,

- the wettabillity examinations of alumina by the melted mixtures of the metallic powders, 
- the wettabillity examinations, by the $\mathrm{AgCu} 28$ solder, of the metallic layers obtained after the mixtures were annealed on the alumina surface and phases formed in the joint,

- the mechanical strength tests of the ceramic joints bonded with the participation of doped copper.

Table 1

Composition of the mixtures used in the experiments (wt\%)

\begin{tabular}{lccccc}
\hline \hline Composition $\mathrm{No}$ & $\mathrm{Cu}$ & $\mathrm{Cu}_{2} \mathrm{O}$ & $\mathrm{CuO}$ & $\mathrm{Ti}$ & $\mathrm{Ag}$ \\
\hline 1 & 95 & - & - & 5 & - \\
\hline 2 & 85 & - & - & 5 & 10 \\
\hline 3 & 85 & 10 & - & 5 & - \\
\hline 4 & 90 & 10 & - & - & - \\
\hline 5 & 80 & 20 & - & - & - \\
\hline 6 & 70 & 30 & - & - & - \\
\hline 7 & 50 & 50 & - & - & - \\
\hline 8 & 50 & - & 50 & - & - \\
\hline
\end{tabular}

Samples intended for examining the surface changes that have taken place on alumina and the alumina single crystal during annealing with doped copper were prepared by depositing paste, made of metallic powder mixtures and an organic carrier (nitro-cellulose binder), on their surface. The mixtures were annealed in a belt furnace in a nitrogen atmosphere and in a vacuum furnace at $10^{-5} \mathrm{~Pa}$ at temperatures of 980 , 1050,1070 and $1100^{\circ} \mathrm{C}$. The surface phase changes and the microstructure at the ceramic/metallic layer interface were examined by the X-ray diffraction method and by micro-analyses with the use of SEM (Scanning electron microscope AURIGA CrossBeam Workstation Carl Zeiss) and EDX (measurement parameters - HV: $20 \mathrm{kV}$, WD: $14.0 \mathrm{~mm}$ ). The phase composition of the ceramic surfaces after annealing was examined in a Siemens D500 X-ray diffractometer equipped with a highresolution $\mathrm{Si}(\mathrm{Li})$ semiconductor detector using a $\mathrm{Cu}$ lamp with $\mathrm{K}_{\alpha}$ radiation of the wavelength $\lambda=1.541 \stackrel{\circ}{\mathrm{A}}$. The $2 \theta$ angle ranged from 10 to $60^{\circ}$. The measurements were performed by the step method at the $2 \theta$ increment $\Delta 2 \theta=0.05^{\circ}$ and a counting time of $4 \mathrm{~s} / \mathrm{step}$.

The samples intended for examining the wettabillity of the powder mixtures with the compositions 1, 2, 3, and 6 (Table 1) were pressed to obtain plates $3 \mathrm{~mm}$ in diameter and $3 \mathrm{~mm}$ thick and, then, melted on alumina and alumina single crystal at a temperature of $1100,1200,1250,1270$ and $1300^{\circ} \mathrm{C}$ in vacuum. The wetting angle was determined on the solidified semi-sphere of the molten drop using the software written at ITME.

The joints made with the participation of metallic layers (compositions according to Table 1) were prepared using the two procedures:

1. After depositing the metallic paste made of the powders with the compositions as given in Table 1, the small beams were annealed at a temperature of $1070^{\circ} \mathrm{C}$ (layers with oxygen in nitrogen and those with titanium - in vacuum) and, then, bonded at $850^{\circ} \mathrm{C}$ in nitrogen using the $\mathrm{AgCu} 28$ solder.
2. Directly after depositing the paste, the small rods were joined without the solder by annealing at a temperature of $1070^{\circ} \mathrm{C}$ in vacuum when copper was doped with titanium and in nitrogen in the case of copper doped with oxides $\left(\mathrm{Cu}_{2} \mathrm{O}, \mathrm{CuO}\right)$.

The mechanical strength was examined by subjecting the alumina ceramics beams prepared with copper doped as given in Table 1 to the three-point bending test. The samples intended for this test are shown in Fig. 1.

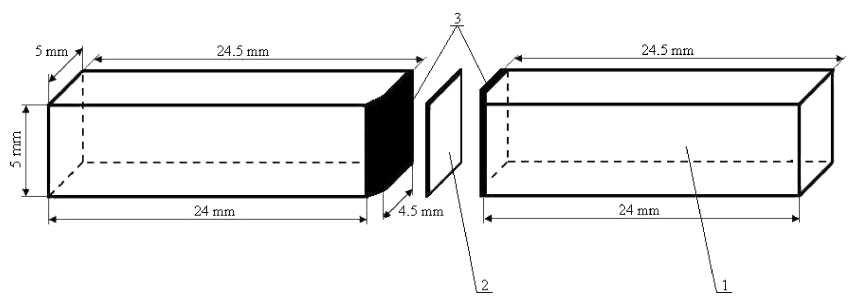

Fig. 1. Sample intended for the bending strength test: 1 - alumina ceramics, 2 - braze material $\mathrm{AgCu} 28$ (thickness $0.1 \mathrm{~mm}$ ), 3 metallic layers

Notched beams were also subjected to the bending test to determine their bending strength $\sigma_{\max }$ and fracture toughness $\mathrm{K}_{I C}$.

The three-point bending tests were performed in a ZWICK 1446 strength machine with a $1 \mathrm{kN}$ head at the support spacing $L=40 \mathrm{~mm}$ and the head travel speed of $0.1 \mathrm{~mm} / \mathrm{min}$. During the test, the deformation as a function of load was recorded. The deformation was measured with a deflection sensor, positioned beneath the sample (at the maximum deflection point).

\section{Results}

The mixtures of copper added with copper oxides and titanium deposited on alumina ceramics and alumina single crystal were subjected to annealing during which metallic layers were formed on the substrate surface. The adhesion test showed that the layers were well bonded with the substrate (no layer detachment was observed). They were also examined for their wettabillity by the $\mathrm{AgCu} 28$ solder. The phase composition of the layers was analyzed using the X-ray diffraction method.

The results of the phase analysis of the layers are shown in Figs. 2 and 3 and in Table 2. Irrespective of the type of the atmosphere and the kind of substrate (alumina single crystal, polycrystalline ceramic) the layers annealed at a given above temperatures, contain the same phases. No phase changes are observed in the layers produced from the copper and oxygencontaining mixtures at 980 and $1050^{\circ} \mathrm{C}$. Beginning from 1070 up to $1250^{\circ} \mathrm{C}, \mathrm{CuAl}_{2} \mathrm{O}_{3}$ and $\mathrm{CuAl}_{2} \mathrm{O}_{4}$ spinels are formed. Titanium oxides appear in all the samples which contain titanium obtained above $980^{\circ} \mathrm{C}$. Like the spinels, the $\mathrm{Cu}_{3} \mathrm{Ti}_{3} \mathrm{O}$ compound is already identified beginning from $1070^{\circ} \mathrm{C}$ up to $1250^{\circ} \mathrm{C}$. 


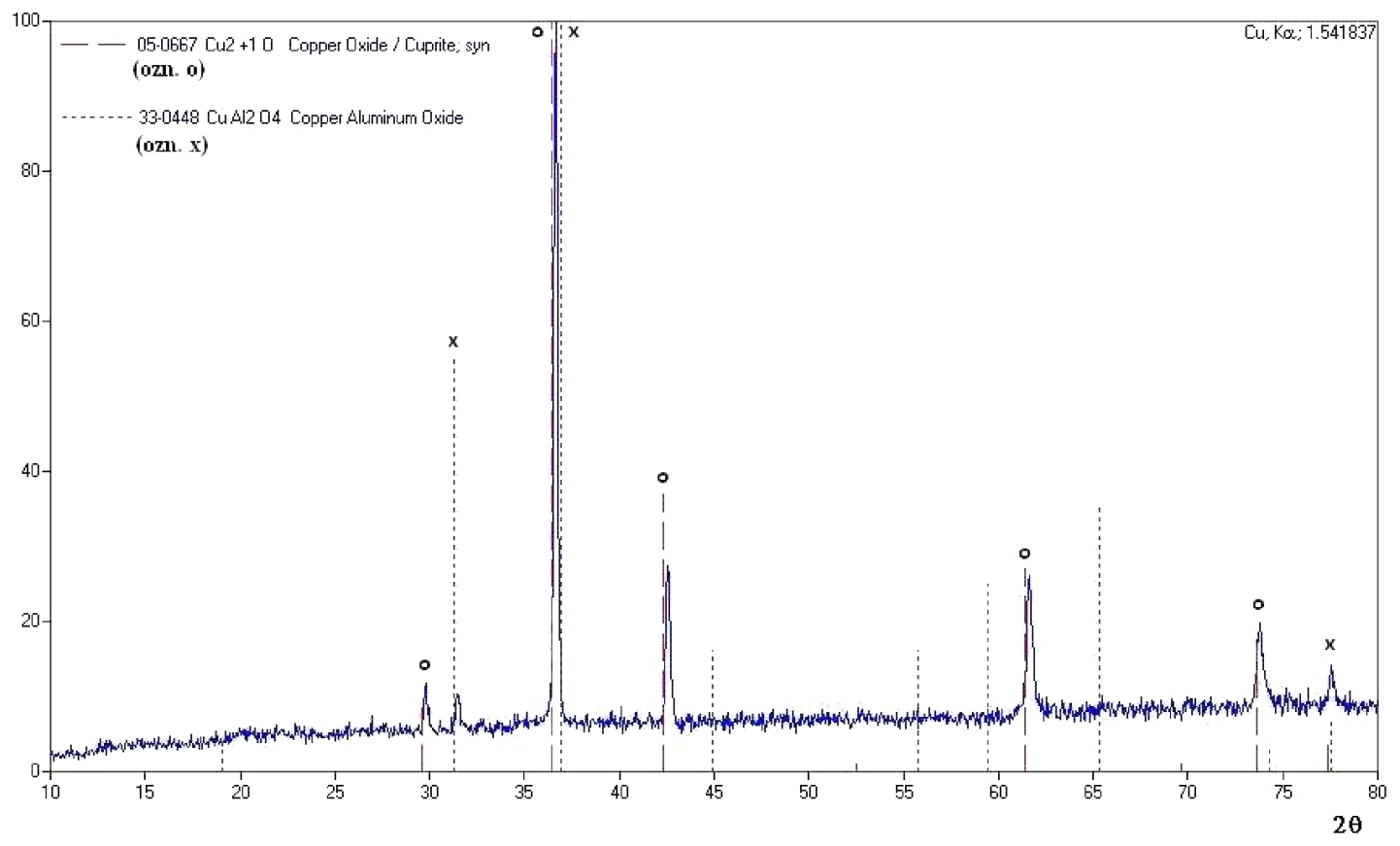

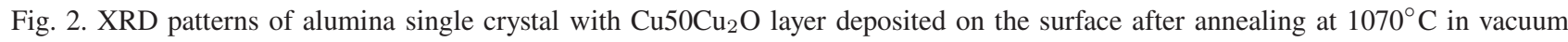

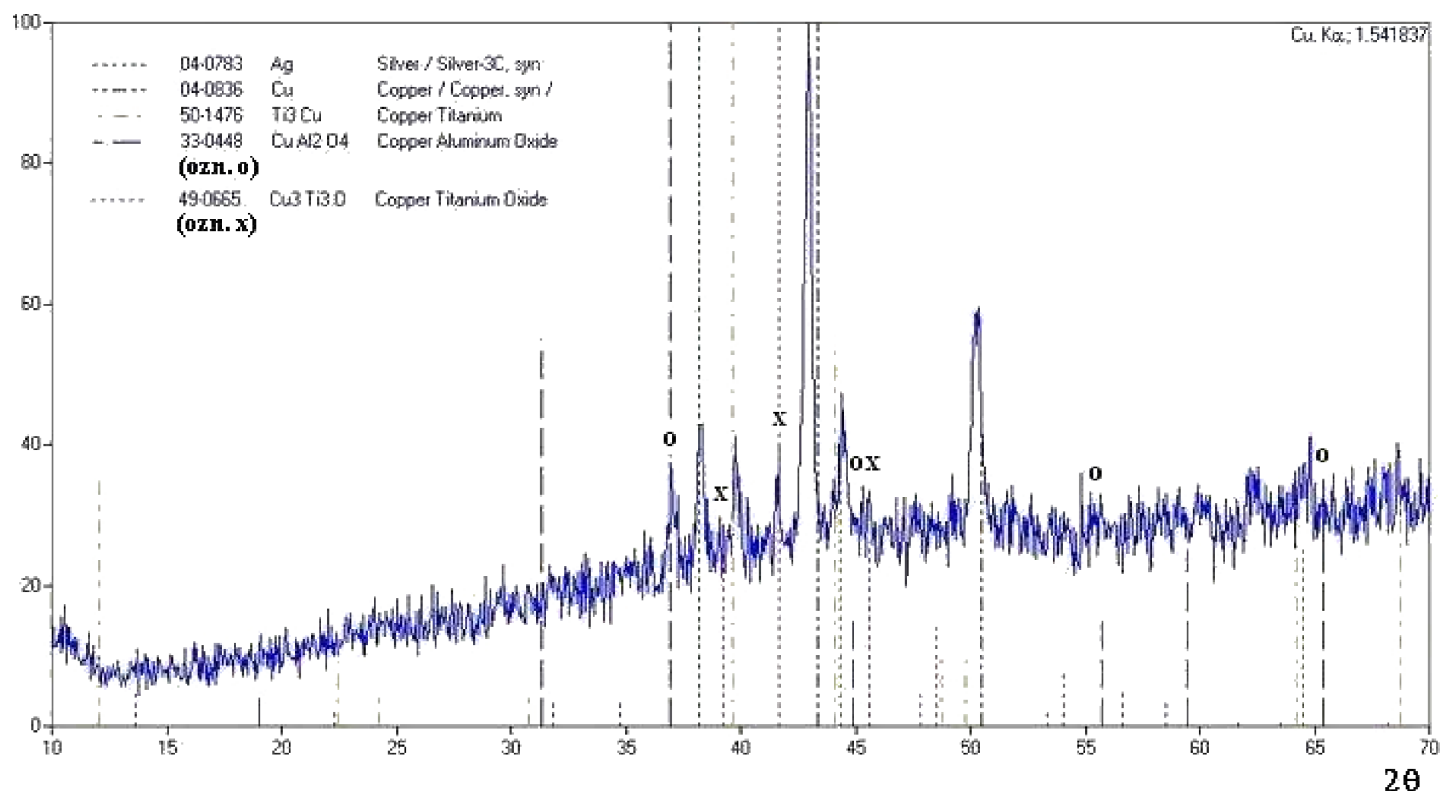

Fig. 3. XRD patterns of alumina ceramics with $\mathrm{Cu} 95 \mathrm{Ti} 5$ layer deposited on the surface after annealing at $1070^{\circ} \mathrm{C}$ in vacuum

Table 2

Results of the X-ray phase identification obtained for the metallic layers which contain: 1-copper with copper oxides (Table 1, items 4,5,6,7,8), 2-copper with titanium (Table 1, items 1,3), 3-copper, titanium, and silver (Table 1, item 2) after annealing on alumina ceramics at $1070^{\circ} \mathrm{C}$ for $15 \mathrm{~min}$

\begin{tabular}{|c|c|}
\hline Atmosphere of annealing & Phase identified \\
\hline Vacuum $10^{-5} \mathrm{~Pa}$ & $\begin{array}{c}\text { 1. } \mathrm{CuAlO}_{2}, \mathrm{CuAl}_{2} \mathrm{O}_{4}, \\
\text { 2. } \mathrm{CuAlO}_{2}, \mathrm{CuAl}_{2} \mathrm{O}_{4}, \mathrm{Cu}_{3} \mathrm{Ti}_{3} \mathrm{O}, \mathrm{Cu}_{3} \mathrm{Ti}_{3}, \mathrm{Ti}_{3} \mathrm{Cu}, \mathrm{Ti}_{2} \mathrm{O}_{3}, \mathrm{TiO}, \mathrm{TiO}_{1,04} \\
\text { 3. } \mathrm{CuAlO}_{2}, \mathrm{CuAl}_{2} \mathrm{O}_{4}, \mathrm{Cu}_{3} \mathrm{Ti}_{3} \mathrm{O}, \mathrm{Cu}_{3} \mathrm{Ti}_{3}, \mathrm{Ti}_{3} \mathrm{Cu}, \mathrm{Ti}_{2} \mathrm{O}_{3}, \mathrm{TiO}, \mathrm{TiAg}, \mathrm{Ag} 0.33 \mathrm{Al} 10.67 \mathrm{Ti}\end{array}$ \\
\hline Nitrogen $1.5 \mathrm{ppm} \mathrm{O}_{2}$ & $\begin{array}{c}\text { 1. } \mathrm{CuAlO}_{2}, \mathrm{CuAl}_{2} \mathrm{O}_{4} \\
\text { 2. } \mathrm{CuAlO}_{2}, \mathrm{CuAl}_{2} \mathrm{O}_{4}, \mathrm{Cu}_{3} \mathrm{Ti}_{3} \mathrm{O}, \mathrm{Cu}_{3} \mathrm{Ti}_{2} \mathrm{Ti}_{3} \mathrm{Cu}, \mathrm{TiO}_{2}, \mathrm{TiO}, \mathrm{TiO}_{1,04}\end{array}$ \\
\hline
\end{tabular}

Table 2 gives the results of the phase examinations in all the layers prepared from the metallic mixtures with the composition according to Table 1 annealed at a temperature of $1070^{\circ} \mathrm{C}$ in nitrogen and vacuum. Irrespective of whether containing copper added with oxides or copper added with titanium, all the layers contained the $\mathrm{CuAlO}_{2}$ and $\mathrm{CuAl}_{2} \mathrm{O}_{4}$ phases. 
In the presence of silver, we obtain intermetallic titaniumaluminum phases $\left(\mathrm{Ag}_{3} \mathrm{Ti}, \mathrm{AlAgTi}\right)$.

The selected diffraction patterns of alumina single crystal and alumina ceramics are shown in Figs. 2 and 3.

Table 2 gives the results of the phase examinations in all the layers prepared from the metallic mixtures with the composition according to Table 1 annealed at a temperature of $1070^{\circ} \mathrm{C}$ in nitrogen and vacuum. Irrespective of the addition type (oxides or titanium) for copper, all the layers contained the $\mathrm{CuAlO}_{2}$ and $\mathrm{CuAl}_{2} \mathrm{O}_{4}$ phases. In the presence of silver, the intermetallic titanium-aluminum phases ( $\mathrm{TiAg}$, Ag0.33Al0.67Ti) were detected.

Annealing at a temperature of $1070^{\circ} \mathrm{C}$ proceeds with the participation of a molten phase which, when the copper is annealed with oxygen, is the $\mathrm{Cu}-\mathrm{Cu}_{2} \mathrm{O}$ eutectic, and when it is annealed with titanium and silver - is molten silver. In both cases the presence of the molten phase favors the synthesis of the spinels and the $\mathrm{Cu}_{3} \mathrm{Ti}_{3} \mathrm{O}$ phase.

The wettabillity of the metallic layers produced of copper doped with oxygen and titanium, annealed at $1070^{\circ} \mathrm{C}$, by the standard commercial $\mathrm{AgCu} 28$ braze material was examined. A specified amount of the solder was melted at a temperature of $850^{\circ} \mathrm{C}$ in vacuum and in nitrogen. In no case, the entire solder over-flew the entire copper layer - in all the samples a solidified droplet of the solder remained on the surface. The best wetting of the surface of the sintered powders was achieved with oxygen-added copper, worse results were obtained with titanium and silver-added copper, and no wetting was observed on the surface of titanium-doped copper.

The wettabillity of alumina ceramics by molten mixtures of copper with copper oxides and copper with titanium was also examined using the procedures given in Table 1, items $1,2,3$, and 7. After subjecting to pressing, the samples were annealed at $1100,1200,1250,1270$ and $1300^{\circ} \mathrm{C}$. All the mixtures melted at a temperature of $1250^{\circ} \mathrm{C}$. At all the examined temperatures and in both atmospheres the mixtures containing titanium did not wet the substrate but formed a molten sphere. After adding $10 \mathrm{wt} \%$ of $\mathrm{CuO}_{2}$ or $10 \mathrm{wt} \%$ of silver, copper added with titanium still did not spread on the surface of neither the single crystal nor alumina ceramics. We found that even $5 \mathrm{wt} \%$ of titanium added to copper has an adverse effect on the wettabillity of corundum by copper alloys.

The surface of corundum, in both the alumina single crystal and alumina ceramics, is only wetted by the coppercopper oxide cermet mixtures in which the $\mathrm{Cu}-\mathrm{CuO} \mathrm{O}_{2}$ eutectic. The image of alumina single crystal sample after melting of $50 \mathrm{wt} \% \mathrm{Cu}+50 \mathrm{wt} \% \mathrm{Cu}_{2} \mathrm{O}$ mixture is shown in Fig. 4. In the samples with the composition $50 \mathrm{wt} \% \mathrm{Cu}$ and $50 \mathrm{wt} \%$ $\mathrm{Cu}_{2} \mathrm{O}$ annealed at $1250^{\circ} \mathrm{C}$ the wetting angle was $\theta=21^{\circ}$ (average wetting angle - four measurements on the circuit for each sample).

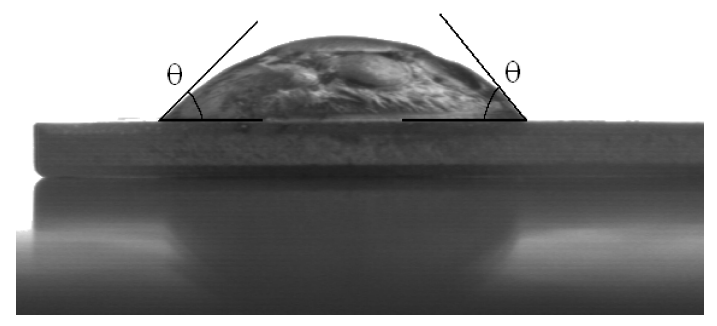

Fig. 4. Wetting angle of alumina single crystal wetted by the $50 \mathrm{wt} \%$ $\mathrm{Cu}+50 \mathrm{wt} \% \mathrm{Cu}_{2} \mathrm{O}$ cermet mixture at a temperature of $1270^{\circ} \mathrm{C}$ in vacuum

As the temperature increases, the wetting angle also increases to $\theta=37^{\circ}$ at $1270^{\circ} \mathrm{C}$ and to $\theta=48^{\circ}$ at $1300^{\circ} \mathrm{C}$. This increase is due to the enhanced reactivity of the cermet layer with the substrate. The appearance of the alumina single crystal surface together with the copper-oxygen sample and copper-titanium sample after annealing at $1270^{\circ} \mathrm{C}$ is presented in Fig. 5.

In both samples we can see changes on the crystal surface. In the joint with the $\mathrm{Cu}_{85} \mathrm{Cu}_{2} \mathrm{O} 10 \mathrm{Ti} 5$ mixture it is a thin continuous film of the melted eutectic (Fig. 5a), whereas in the joint with the Cu95Ti5 mixture we only have crystalline precipitates (Fig. 5b). a)

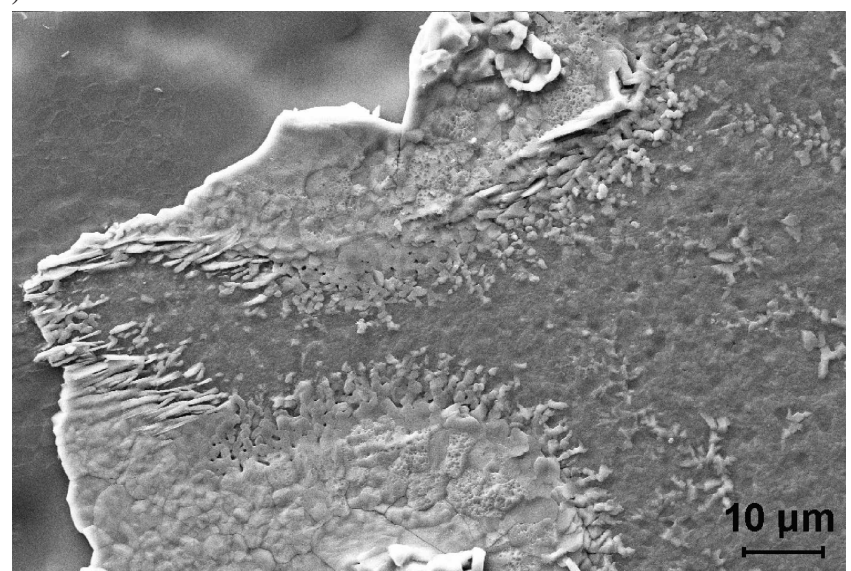

b)

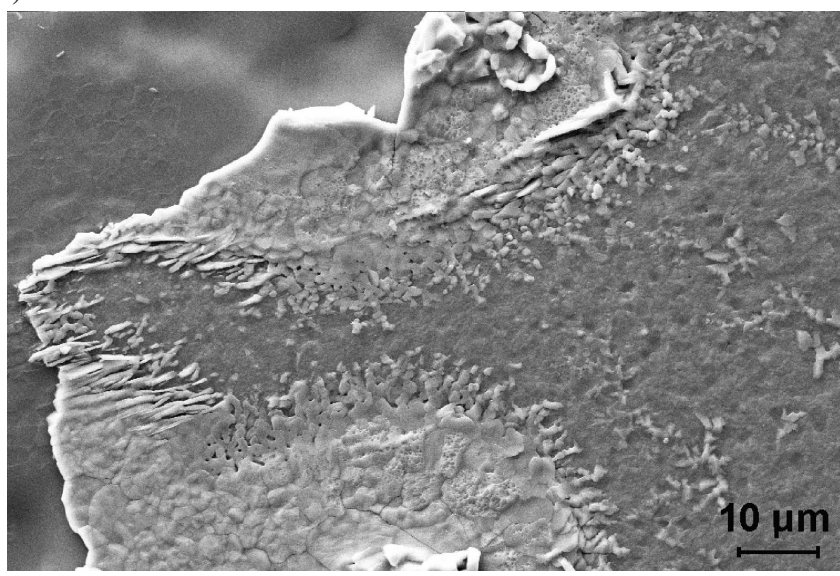

Fig. 5. Appearance of the surfaces of alumina single crystal: (a) $\mathrm{Cu} 85 \mathrm{Cu}_{2} \mathrm{O} 10 \mathrm{Ti} 5$ sample, and (b) $\mathrm{Cu} 95 \mathrm{Ti} 5$ sample, both melted at $1270^{\circ} \mathrm{C}$ 
Table 3

Bending strength of the joints with the participation of titanium (A) direct bonding, (B) bonding with the AgCu28 solder (the average value of 5 measurements)

\begin{tabular}{cccc}
\hline \hline \multicolumn{2}{l}{ Interlayer composition according to Table 1 } & Bending strength $\sigma_{g}[\mathrm{MPa}]$ & Fracture toughness $K_{I c}[\mathrm{MPam}]^{1 / 2}$ ) \\
\hline $\begin{array}{c}\text { 85Cu10Ag5Ti } \\
\text { (p. 2, tabl. 1) }\end{array}$ & $\mathrm{A}$ & $34.0+/-20$ & $1.8+/-0.7$ \\
\hline $\begin{array}{c}\text { 85Cu10Cu} \\
\text { (p. } 3 \text { 5 } \text { tabl. 1) }\end{array}$ & $\mathrm{B}$ & $54.0+/-8$ & $2.6+/-0.6$ \\
\cline { 2 - 4 } & $\mathrm{A}$ & $48.0+/-15$ & $2.2+/-0.6$ \\
\hline
\end{tabular}

Table 4

Bending strength of the joints bonded with oxygen-doped copper (A) direct bonding, (B) bonding with the AgCu28 solder (the values are the averages from 5 measurements)

\begin{tabular}{cccc}
\hline \hline \multicolumn{2}{l}{ Interlayer composition according to Table 1} & Bending strength $\sigma_{g}[\mathrm{MPa}]$ & Fracture toughness $\left.K_{I c}[\mathrm{MPam}]^{1 / 2}\right)$ \\
\hline $\begin{array}{l}90 \mathrm{Cu} 10 \mathrm{Cu}_{2} \mathrm{O} \\
(\text { p. 4, table 1) }\end{array}$ & A & $63.0 \pm 8.7$ & $3.1 \pm 0.3$ \\
\hline $\begin{array}{l}80 \mathrm{Cu} 20 \mathrm{Cu}_{2} \mathrm{O} \\
(\text { p. 5, table 1) }\end{array}$ & B & $29.8 \pm 12.7$ & $1.6 \pm 0.7$ \\
\hline $\begin{array}{l}70 \mathrm{Cu} 30 \mathrm{Cu}_{2} \mathrm{O} \\
(\text { p. 6, table 1) }\end{array}$ & A & $59.0 \pm 16.0$ & $2.5 \pm 0.6$ \\
\hline $\begin{array}{l}50 \mathrm{Cu} 50 \mathrm{Cu}_{2} \mathrm{O} \\
(\text { p. 7, table 1) }\end{array}$ & B & $34.4 \pm 14.0$ & $1.7 \pm 0.5$ \\
\hline
\end{tabular}

The mechanical strength of the ceramic/copper joints strongly depends on the phase changes that occur in the nearsurface layer of alumina during annealing with oxygen-doped and titanium-doped copper, the wettability of alumina substrates by copper with these two compositions, and the wettability of the copper layers by various solders.

We also examined the strength parameters of the joints bonded directly through metallic layers produced from powders, and of the joints bonded with the use of the $\mathrm{AgCu} 28$ solder, with the alumina being pre-coated with copper layers and then annealed (oxygen-doped copper - in nitrogen, doped with titanium - in vacuum).

The measured strength values are very varied, especially in the joints bonded directly through the 95Cu5Ti layers. The chosen results for joint obtained using layers with $\mathrm{Ti}$ are given in Table 3.

The strength of joints bonded directly by Cu95Ti5 layer and additionally brazed by $\mathrm{AgCu} 28$ braze material was very low. The silver's addition to copper-titanium mixture causes a substantial increase of the joints strength and repeatability of the results. The strength of the directly obtained joints was $40 \%$ lower than those brazed with $\mathrm{AgCu} 28$ braze material. The example of deformation curve of loaded joints is shown in Fig. 7. The joints obtained using layers consisting of copper with copper oxide and titanium irrespectively of the bonding way, are characterized by high mechanical strength (48 MPa).

Table 4 and Fig. 6 show the bending strength of the joints bonded with oxygen-doped copper. The fracture toughness $K_{I C}$ of these joints, both brazed and directly bonded, exceed that of the joints bonded with titanium-doped copper even by $60 \%$.

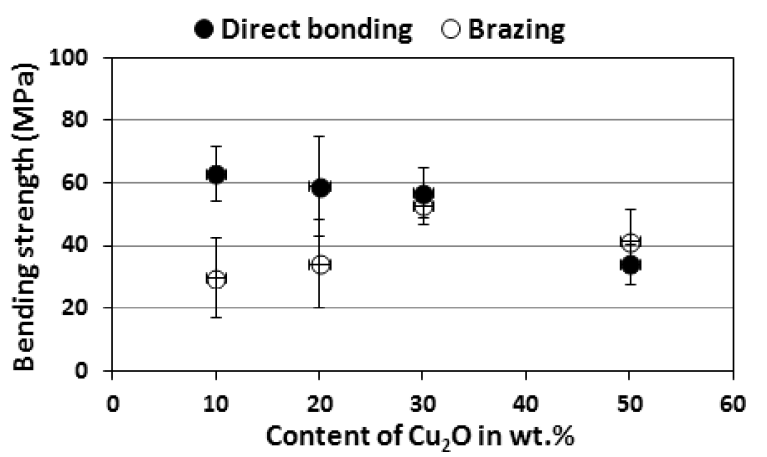

Fig. 6. Bending strength depending on the copper oxide content in the metallic layer

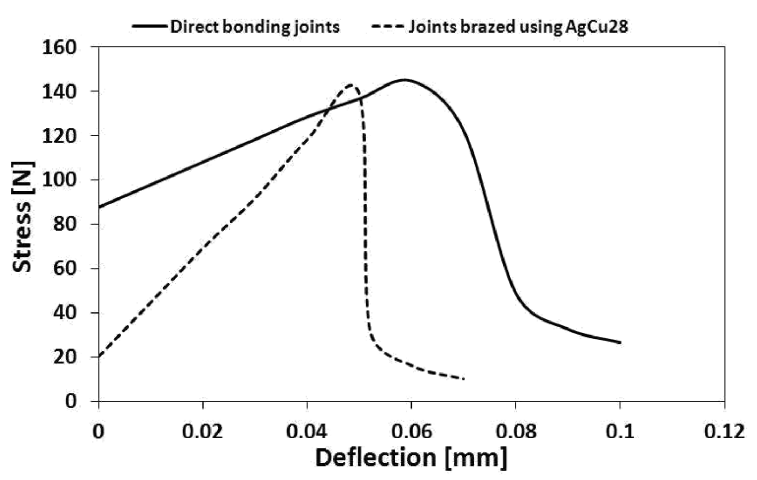

Fig. 7. Deformation of the joints under load (solid line - sample prepared acc. to item 6 , Table 1), dashed line - sample prepared acc. to item 3, Table 1)

The higher bending strength was obtained in the joints bonded directly through the metallic layer composed of copper doped with 10 to $30 \%$ of $\mathrm{Cu}_{2} \mathrm{O}$ (Fig. 6).

The strength of the joints brazed directly through a $\mathrm{Cu}_{2} \mathrm{O}$ doped copper layer is high and depends on the $\mathrm{Cu}_{2} \mathrm{O}$ content: 
with $10-30 \mathrm{wt} \% \mathrm{Cu}_{2} \mathrm{O}$ the strength values are similar, whereas with $50 \mathrm{wt} \% \mathrm{Cu}_{2} \mathrm{O}$ they are reduced by half. The joints with the copper/copper oxide layer, joined using the brazed material, have a considerably lower strength than the directly bonded joints. Up to $30 \mathrm{wt} \%$ of $\mathrm{Cu}_{2} \mathrm{O}$, the strength of the directly bonded joints is almost twice as high as that of the brazed joints. In these joints, the relationship between the strength and the $\mathrm{Cu}_{2} \mathrm{O}$ content is conversed: at small $\mathrm{Cu}_{2} \mathrm{O}$ contents the strength is low, whereas beginning from $30 \mathrm{wt} \%$ it greatly increases and remains unchanged up to $50 \mathrm{wt} \%$ of $\mathrm{Cu}_{2} \mathrm{O}$.

The value of fracture toughness of the joint with high mechanical strength is from 2.6 to $3.1 \mathrm{MPam}^{1 / 2}$ irrespectively from the producing way and the kind of metallic layers used. The comparison of deformation curves registered during process of joints loading is shown in Fig. 7.

The direct joint obtained using copper layers with addition of copper oxide, while loaded show bigger deformation than brazed joint with layers containing copper, silver and titanium layer.

At increased oxygen contents, the surface phenomena may degrade the strength of the ceramic. At $50 \%$ of $\mathrm{Cu}_{2} \mathrm{O}$ the liquid oxygen-copper phases migrate along the corundum grain boundaries to a considerable depth (Fig. 8). With $50 \%$ of $\mathrm{Cu}_{2} \mathrm{O}$ in copper, the migration of these phases along the grain boundaries is visible at a depth above $5 \mu \mathrm{m}$.

A similar migration of the metallic phases deep into the ceramic is observed after annealing the $\mathrm{Cu} 85 \mathrm{Ag} 10 \mathrm{Ti} 5$ layers. Figure 9 shows cross-sections of these layers and the surface distribution of the elements.

On the ceramic surface we have silver with titanium, whereas copper with titanium penetrate along the ceramic grain boundaries to a depth of about $5 \mu \mathrm{m}$, just as does copper in the $\mathrm{Cu} 50 \mathrm{wt} \%-\mathrm{Cu}_{2} \mathrm{O} 50 \mathrm{wt} \%$ layers. In both cases the presence of the metallic phases in the inter-granular spaces of alumina ceramics may adversely affect its mechanical strength. The highest strength was obtained in the joint in which the ceramic was bonded with copper added with $20 \% \mathrm{Cu}_{2} \mathrm{O}$. The ceramic/copper interface layer in this joint can be seen in Fig. 10. On the alumina ceramics surface we can see a homogeneous transition layer, about $1 \mu \mathrm{m}$ thick, composed of oxygen and copper. The linear distribution of these elements is shown in Fig. 11. We can infer from this figure that a chemical compound has formed there, which in this case is $\mathrm{CuAlO}_{2}$.

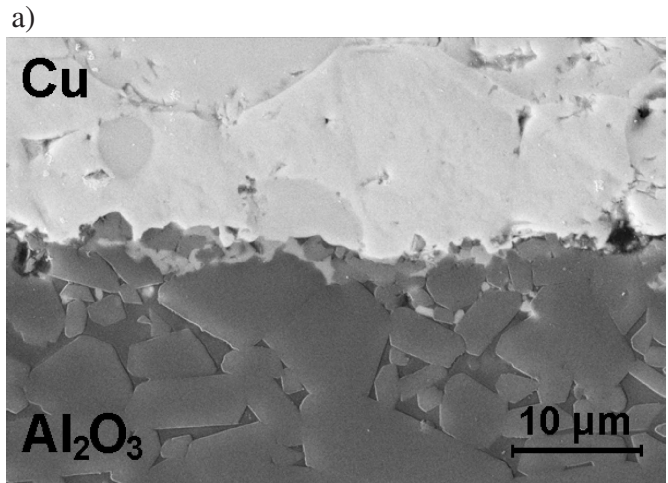

b)

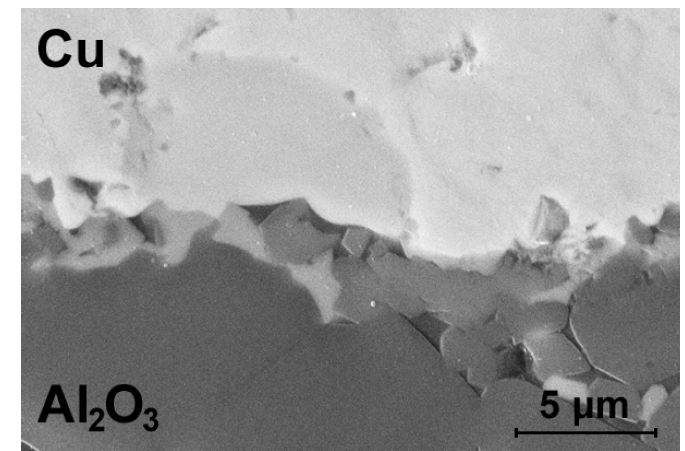

Fig. 8. Cross-section of the metallic layer of the $\mathrm{Cu} 50 \mathrm{wt} \%-\mathrm{Cu}_{2} \mathrm{O} 50 \mathrm{wt} \%$ cermet annealed on alumina at $1070^{\circ} \mathrm{C}$ in nitrogen
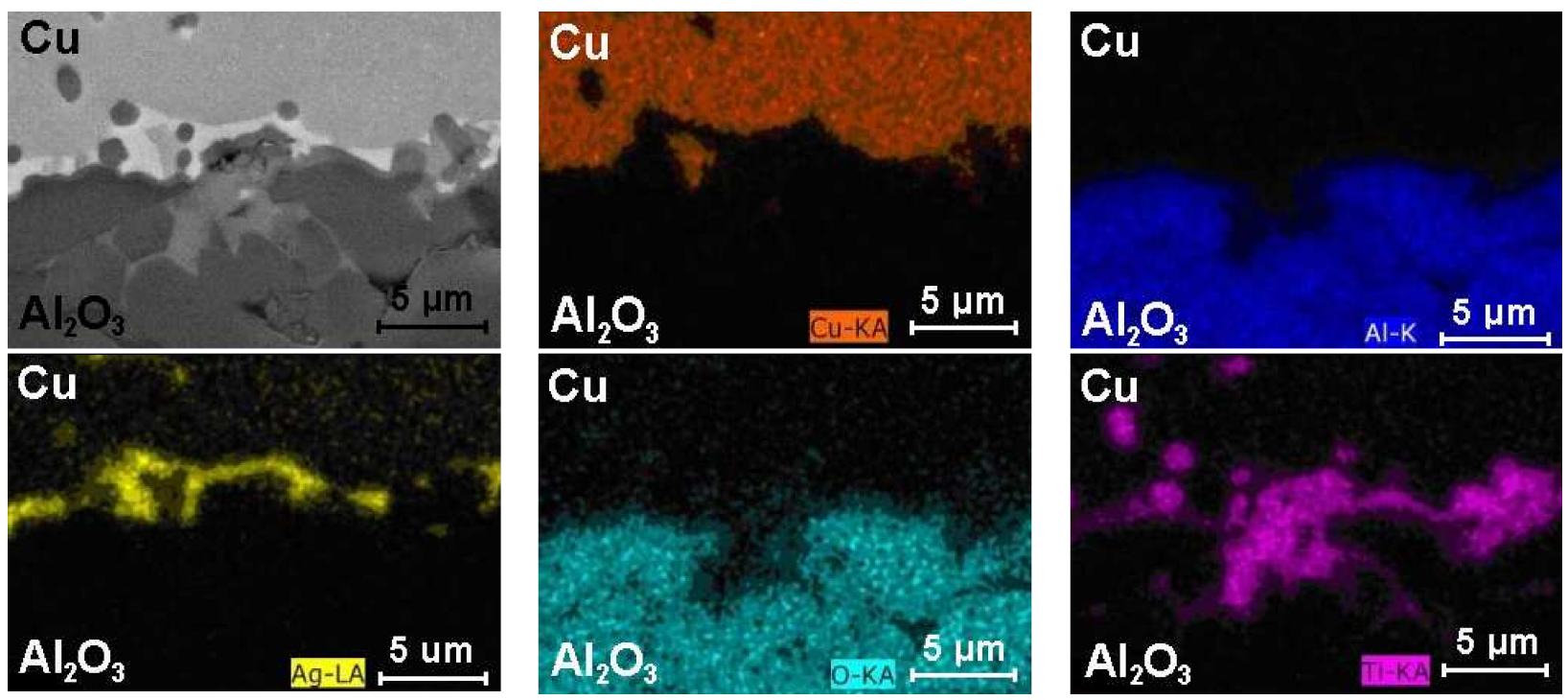

Fig. 9. Cross-section and surface element distribution in the $\mathrm{Cu} 85 \mathrm{Ag} 10 \mathrm{Ti} 5$ layer annealed on corundum at $1070^{\circ} \mathrm{C}$ in vacuum 
a)

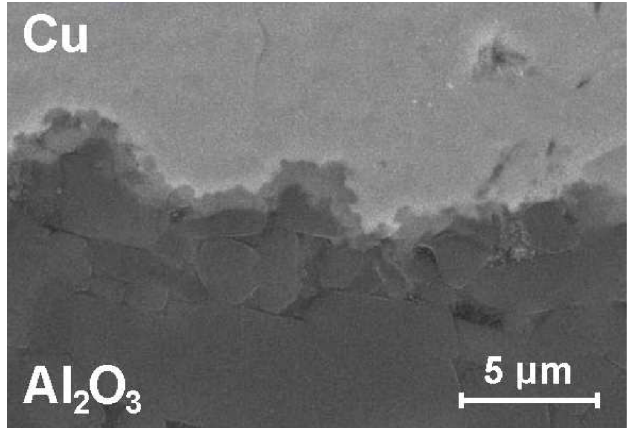

c)

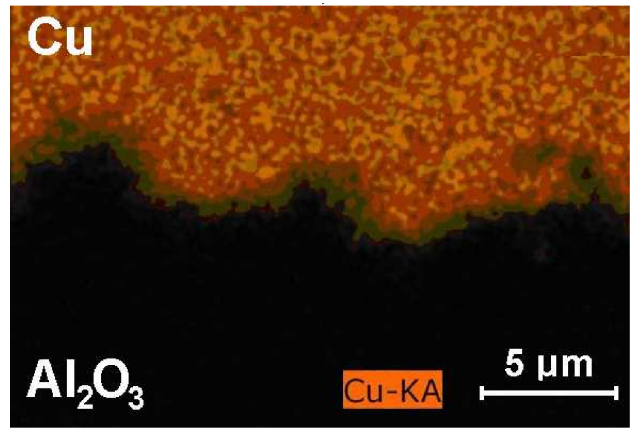

b)

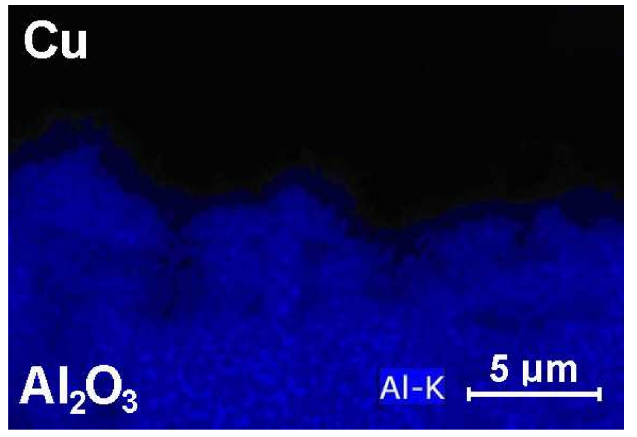

d)

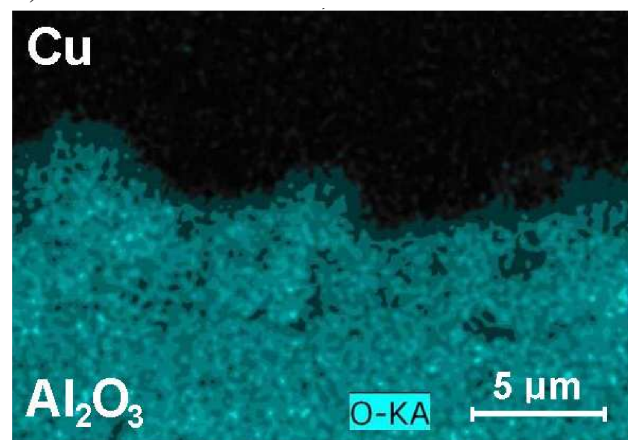

Fig. 10. Cross-section of alumina ceramics with $20 \% \mathrm{Cu}_{2} \mathrm{O}$-added copper after annealing at $1070^{\circ} \mathrm{C}$ in nitrogen (a) and the surface distribution of aluminum (b), copper (c) and oxygen (d)

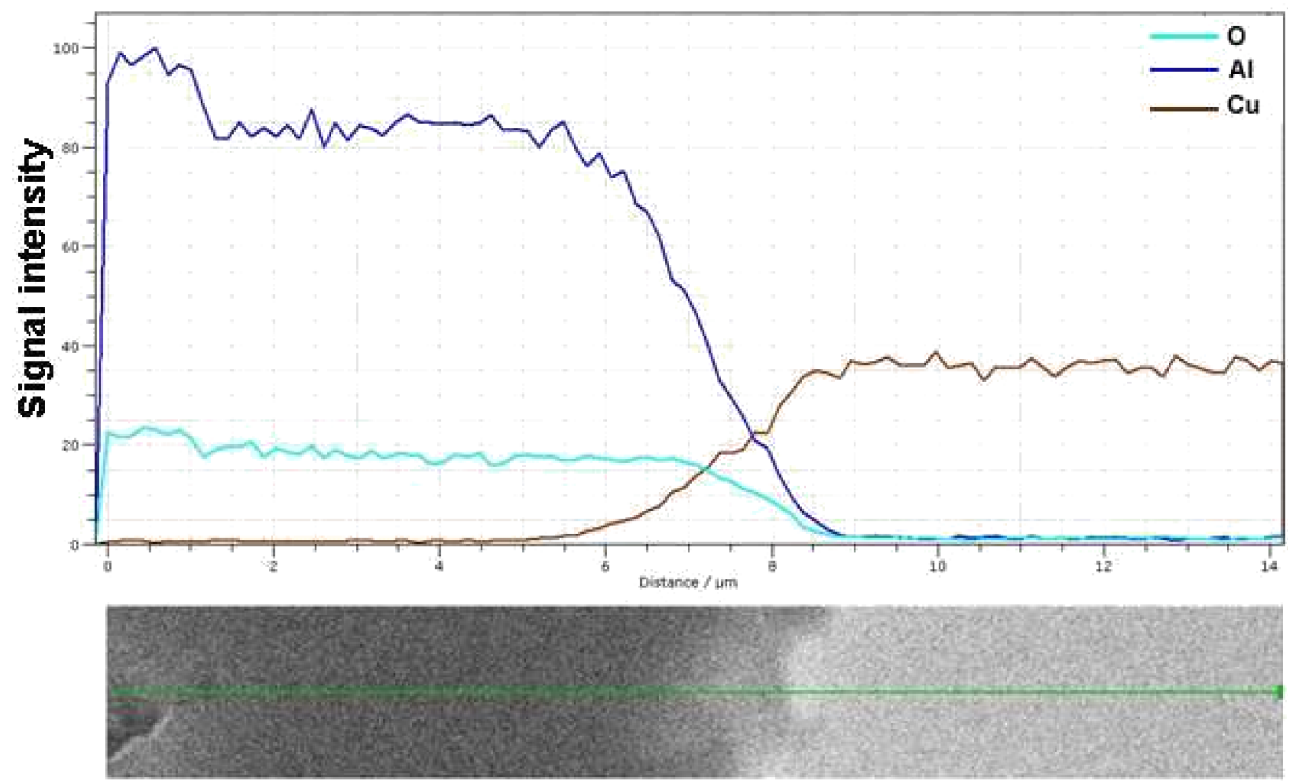

Fig. 11. Linear element distribution on the alumina ceramics - copper layer cross-section shown in Fig. 8

\section{Discussion}

During annealing of alumina ceramics with $\mathrm{Cu}_{2} \mathrm{O}$ or $\mathrm{CuO}$ oxides in vacuum or nitrogen, the reactions proceed as described in the Introduction. New phases appear, such as the $\mathrm{Cu}-\mathrm{Cu}_{2} \mathrm{O}$ eutectic and $\mathrm{CuAlO}_{2}$ and $\mathrm{CuAl}_{2} \mathrm{O}_{4}$ spinels, which bind the two materials. The mechanical strength of these joints depends on the amount of active oxygen. The highest strength and its best reproducibility ( $\pm 8 \mathrm{MPa}$ ) was achieved in the alumina ceramics - copper joint with copper containing 10 $30 \mathrm{wt} \% \mathrm{Cu}_{2} \mathrm{O}$, annealed at $1070^{\circ} \mathrm{C}$. At higher oxygen contents the liquid phases that form during the annealing process migrate into the ceramic to considerable depths (above $5 \mu \mathrm{m}$ ). In effect, the strength of the surface layer of the ceramic decreases and, on failure of the joint, alumina ceramics agglomerates containing several grains are falling out. 
During annealing alumina ceramics with titanium-doped copper, the principal role is played by oxidation of titanium, which, in the conditions prevailing during our experiments, proceeds chiefly through the reduction of alumina ceramics according to the formula:

$$
\mathrm{Al}_{2} \mathrm{O}_{3}{ }^{\mathrm{Ti}} \rightarrow 2[\mathrm{Al}]+3[\mathrm{O}]
$$

$\mathrm{TiO}_{2}, \mathrm{Ti}_{2} \mathrm{O}_{3}, \mathrm{TiO}$, and $\mathrm{TiO}_{1.04}$ oxides appear, and, in addition, titanium reacts with copper to form $\mathrm{Cu}_{3} \mathrm{Ti}$ which, in the presence of active oxygen, participates in the formation of the $\mathrm{M}_{6} \mathrm{O}$ phases [1] according to the reaction:

$$
\mathrm{Cu}_{3} \mathrm{Ti}+1 / 6 \mathrm{O}_{2} \rightarrow 1 / 3 \mathrm{Cu}_{3} \mathrm{Ti}_{3} \mathrm{O}+2 \mathrm{Cu} \text {. }
$$

The activity of titanium towards the substrate is confirmed by its increased concentration on the surface of the alumina single crystal (Fig. 13b). Although some precipitates exist in the entire of the copper.

Cross-sections of the $\mathrm{Cu} 50 \mathrm{Cu}_{2} \mathrm{O} 50$ and $\mathrm{Cu} 95 \mathrm{Ti} 5$ layers after annealing on the alumina single crystal at $1250^{\circ} \mathrm{C}$ in vacuum are shown in Figs. 12 and 13. On the alumina single crystal we can see a transition layer composed of newly formed phases which in the case of oxygen-doped copper is crystalline and continuous, whereas with titanium-doped copper its structure is different. In both samples, the transition layer is in continuous contact with the substrate.

b)

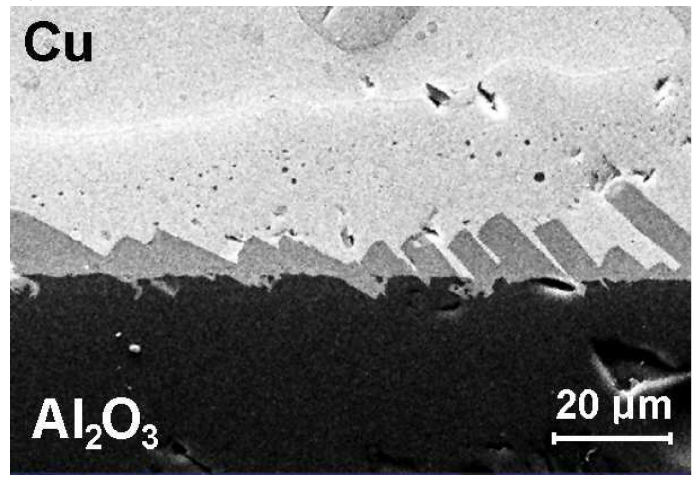

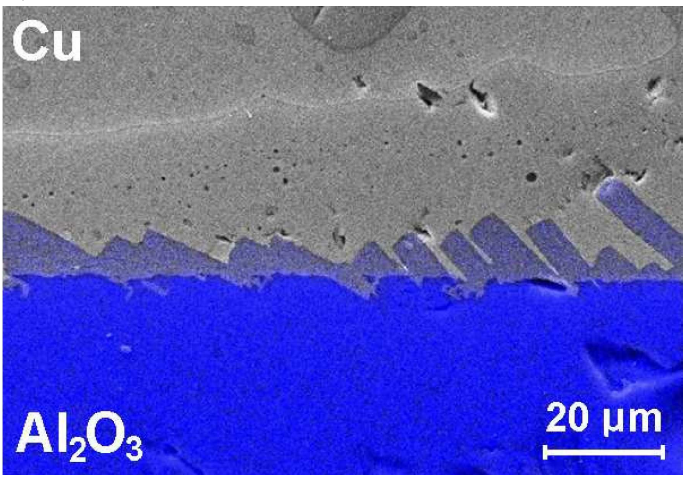

Fig. 12. Cross-section (a) and distribution of aluminum (b) in a alumina single crystal - copper $\left(\mathrm{Cu}_{50}-\mathrm{Cu}_{2} \mathrm{O} 50\right)$ joint after annealing at $1250^{\circ} \mathrm{C}$ in vacuum

a)

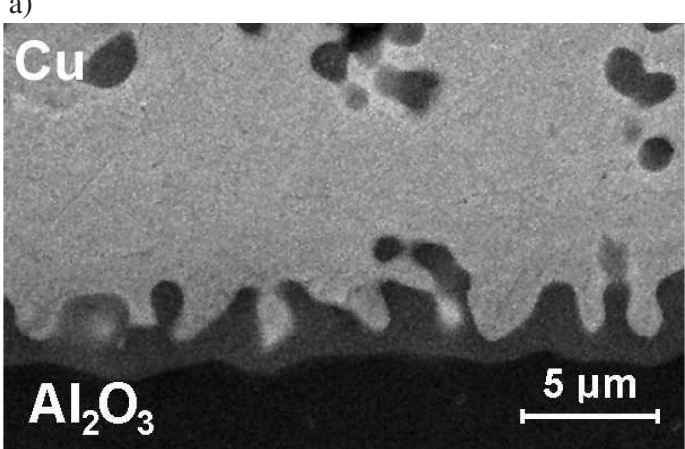

b)

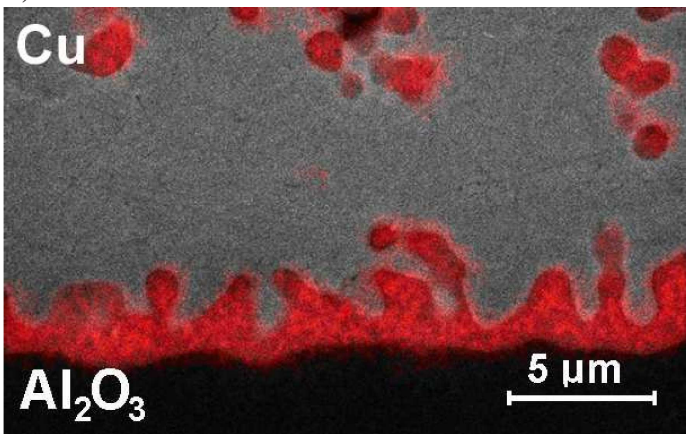

Fig. 13. Cross-section of a alumina single crystal - copper (Cu95Ti5) joint (a) and the distribution of titanium (b) after annealing at $1250^{\circ} \mathrm{C}$ in vacuum
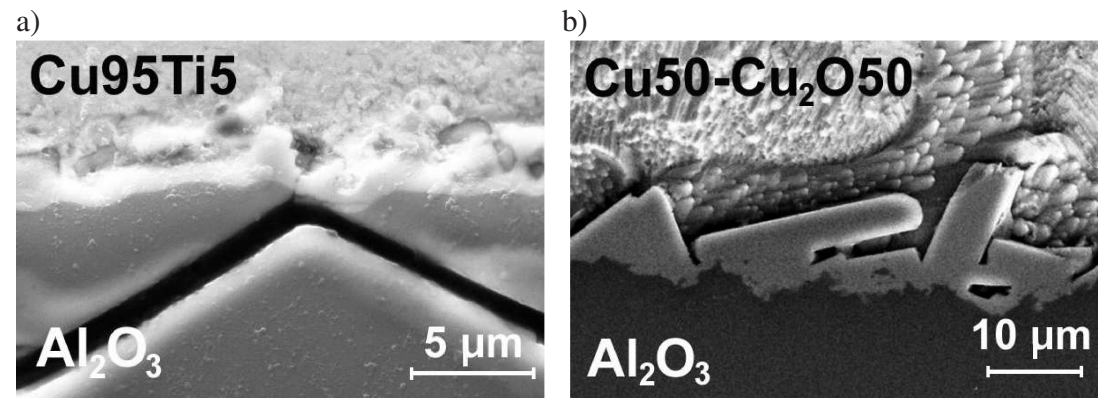

Fig. 14. Metallographic cross-sections of the transition layers shown in Figs 12 and 13 after etching with 5\% nitric acid: (a) alumina single crystal - $\mathrm{Cu} 95 \mathrm{Ti5}$, (b) alumina single crystal - $\mathrm{Cu} 50-\mathrm{Cu}_{2} \mathrm{O} 50$ 
The strength of the joints bonded with oxygen-activated copper is higher than that of the joints brazed with titaniumactivated copper. Although the strength values may be considered satisfactory, to meet the reliability requirements we should indicate the joints bonded with copper-copper oxide as more advantageous in this respect. This suggestion is also confirmed by microscopic observations (Fig. 14) of the transition layers formed on the alumina single crystal after etching with the $5 \%$ nitric acid for $5 \mathrm{~s}$. After the chemicallyunbound copper is removed, we can see the type of bonding of the new phases with the substrate. After the chemical etching, the aluminum-copper spinel formed on the alumina single crystal surface during bonding with oxygen-doped copper remain well bounded with alumina ceramics (Fig. 14b), whereas in the samples with titanium-doped copper no continuity between the new phases and the substrate is observed (Fig. 14a). We can clearly see the reactively etched surface layer of the alumina single crystal.

\section{Conclusions}

Although alumina ceramic is not wetted by molten copper, joining it with copper is possible when the copper is earlier doped with oxygen or titanium. During the high-temperature process conducted with so doped copper, new molten phases are formed, such as copper-oxygen eutectic or copper, silver, titanium alloys, which well wet the ceramic. Irrespective of which of the elements is added to copper, the same aluminumcopper spinal phase is formed in the surface layer of the ceramic. In the case of oxygen-doped copper, the spinel layer grows on alumina ceramics from the cermet mixture. Whereas in the presence of titanium, the aluminum-copper spinel occurs as a result of the alumina ceramics being dissolved, and along with the $\mathrm{Cu}_{3} \mathrm{Ti}_{3} \mathrm{O}$ phase is identified in the transition layer. In both cases, the bond between the two materials is satisfactory, but to achieve high reliability of the joint, the binding phase formed in the transition layer (from the two materials being joined) must be well bonded with the substrate and be located within a medium with high plasticity and with the thermal expansion coefficient close to that of the substrate. This can be achieved with the use of copper/copper oxides cermet mixtures.

\section{REFERENCES}

[1] J.A. Fernie, R.A.L. Drew, and K.M. Knowles, "Joining of engineering ceramics", Int. Materials Reviews 54 (5), 283-331 (2009).

[2] M. Barlak, J. Piekoszewski, J. Stanislawski, Z. Werner, K. Borkowska, M.Chmielewski, B. Sartowska, M. Miskiewicz, W. Starosta, L. Walis, and J. Jagielski, "The effect of intense plasma pulse pre-treatment on wettability in ceramic-copper system", Fusion Engineering and Design 82 (15-24), 2524-2530 (2007).

[3] L. Salbut, M. Kujawinska, M. Jozwik, and D. Golanski, "Investigation of ceramic-to-metal joint properties by hybrid moire interferometry/FEM analysis", Proc. Society of Photo-Optical Instrumentation Engineers (SPIE) 3745, 298-306 (1999).
[4] K. Wojciechowski, R. Zybala, and R. Mania, "High temperature CoSb3 - Cu junctions", Microelectronics Reliability 51, 1198-1202 (2011).

[5] J. Zimmerman, Z. Lindemann, D. Golański, T. Chmielewski, and W. Włosiński, "Modeling residual stresses generated in Ti coatings thermally sprayed on A12O3 substrates", Bull. Pol. Ac.: Tech. 61 (2), 515-526 (2013).

[6] K. Pietrzak, D. Kalinski, and M. Chmielewski, "Interlayer of $\mathrm{Al}_{2} \mathrm{O}_{3}$-Cr functionally graded material for reduction of thermal stresses in alumina - heat resisting steel joints", J. Eur. Ceramic Society 27 (2-3), 1281-1286 (2007).

[7] A. Krajewski, W. Włosinski, T. Chmielewski, and P. Kolodziejczak, "Ultrasonic-vibration assisted arc-welding of aluminum alloys", Bull. Pol. Ac.” Tech. 60 (4), 841-852 (2012).

[8] M. Chmielewski and W. Weglewski, "Comparison of experimental and modelling results of thermal properties in $\mathrm{Cu}-\mathrm{AlN}$ composite materials", Bull. Pol. Ac.: Tech. 61 (2), 507-514 (2013).

[9] L. Jian-Guo, "Wetting of ceramic materials by liquid silicon, aluminium and metallic melts and other reactive elements. A review", Ceramics International 20, 391-412 (1994).

[10] A.P. Tomsia and R.E. Loehman, "Bonding and interfacial reactions in ceramics for microelectric packaging", Fourth EuroCeramics 9, 11-18 (1995).

[11] R. Voytovych, F. Robaut, and N. Eustathopoulos, "The relation between wetting and interfacial chemistry in the CuAgTi/alumina system”, Acta Materialia 54, 2205-2214 (2006).

[12] M. Książek, B. Mikułowski, N. Sobczak, W. Radziwiłł, and M. Radecka, "Influence of $\mathrm{SnO}_{2}$ layer coated on an aluminium oxide substrate on wettability and strength of the connection in the $\mathrm{Cu} / \mathrm{Al}_{2} \mathrm{O}_{3}$ system", Ceramika/Ceramics 91, 677-684 (2005), (in Polish).

[13] L. Stobierski, Carbon Ceramics, AGH, Cracow, 2005.

[14] G.P. Kelkar and A.H. Carim, "Synthesis, properties and ternary phase stability of $\mathrm{M}_{6} \mathrm{X}$ compounds in the TiCuO system", $J$. American Ceramic Society 76 (7), 1818-1820 (1993).

[15] W. Olesinska, M. Pawłowska, D. Kalinski, and M. Chmielewski, Reactive metallic layers produced on $\mathrm{AlN}, \mathrm{Si}_{3} \mathrm{~N}_{4}$ and $\mathrm{SiC}$ ceramics, J. Materials Science: Materials in Electronics 15, 813-817 (2004).

[16] W. Olesinska, D. Kalinski, M. Chmielewski, R. Diduszko, and W.K. Włosinski, "Influence of titanium on the formation of a "barier" layer during joining on AlN ceramic with copper by the CDB technique", J. Materials Science: Materials in Electronics 17, 781-788 (2006).

[17] M. Barlak, W. Olesinska, J. Piekoszewski, M. Chmielewski, J. Jagielski, D. Kalinski, Z. Werner, and W. Szymczyk, "Ion implanted nanolayers in AIN for direct bonding with copper", Solid State Phenomena 99-100, 231-234 (2004).

[18] M. Barlak, W. Olesinska, J. Piekoszewski, M. Chmielewski, J. Jagielski, D. Kalinski, Z. Werner, and B. Sartowska, "Ion implantation as a pre-treatment method of AlN substrate for direct bonding with copper", Vacuum 78 (2-4), 205-209 (2005).

[19] M. Barlak, W. Olesinska, J. Piekoszewski, Z. Werner, M. Chmielewski, J. Jagielski, D. Kalinski, B. Sartowska, and K. Borkowska: "Ion beam modification of ceramic component prior to formation of AlN-Cu joints by direct bonding process", Surface \& Coatings Technology 201, 8317-8321 (2007). 